\title{
The Legislative Response to the Shareholders $v$ Stakeholders debate: a Comparative Overview
}

\author{
Sulette Lombard and Tronel Joubert*
}

The debate as to whose interests should be considered by directors in terms of their duty to act in the best interests of the corporation-shareholders or stakeholders-has been popular among corporate law scholars for a number of years. In some jurisdictions the judiciary indicated a willingness to depart from a strict shareholder-centric approach by recognising that the interests of creditors become paramount under certain circumstances. Until relatively recently the legislature remained silent on this topic. However, corporate law reform afforded the legislature an opportunity to revisit this debate in at least four common law jurisdictions-Australia, the UK, South Africa and Singapore. This article provides a comparative overview and analysis of relevant legislation in these jurisdictions to illustrate the extent to which, if at all, the legislatures in these jurisdictions have been persuaded to depart from the notion of shareholder supremacy and ultimately assesses the implications of a particular approach adopted by the respective legislatures.

\section{A. Introduction}

The debate as to whether the corporate constituency should be expanded so as to provide for the interests of corporate stakeholders other than shareholders, and how this should be done, has been popular among corporate law scholars for a number of years ${ }^{1}$ and remains an important one today. ${ }^{2}$ This ongoing debate has given rise to a number of proposed corporate governance models related to particular theories on the nature of corporation.3 At opposite

\footnotetext{
Sulette Lombard, BLC, LLB, LLM, LLD, Senior Lecturer in Law, Flinders University Law School, Australia; Tronel Joubert, LLB, LLM, Lecturer in Law, University of Pretoria Law Faculty, South Africa.

1 P Bradley, "BCE Inc v 1976 Debentureholders: The New Fiduciary Duties of Fair Treatment, Statutory Compliance and Good Corporate Citizenship" (2009-10) 41 Ottawa Law Review 325,333 observes that "the stakeholder debate is nearly as old as the concept of a corporation itself". One of the most well-known examples of such a debate is the one between Professors Berle and Dodd. See EM Dodd Jr, "For Whom Are Corporate Managers Trustees" (1932) 45 Harvard Law Review 1145; AA Berle Jr, "For Whom Corporate Managers Are Trustees: A Note" (1932) 45 Harvard Law Review 1365. This debate remains important.

2 PL Davies, Gower and Davies Principles of Modern Company Law (8th edn, Sweet \& Maxwell 2008) 507 , notes that the "theoretical or even ideological significance of the debate about the correct formulation of the basic loyalty duty cannot be easily over-estimated".
} 
ends of the spectrum are the shareholder-primacy model, which is closely aligned with the traditional viewpoint that the interests of the company are to be defi ned with reference to the interests of its shareholders, and the stakeholder model, which recognises that companies and corporate conduct impact on a wide category of persons involved with the company (the so-called "stakeholders" of the company), and that their interests in the company should also be protected. Other models situated somewhere between these two extremes have also been suggested. 4

A signifi cant focus of this debate is directors' duty to act in the "interests of the company" and the consequent identification of the "interests of the company". 5 The traditional viewpoint embraces the shareholder-primacy model and proposes that the interests of the company are to be equated with those of its shareholders. This model is based on pronouncements by the court in cases such as Greenhalgh v Arderne Cinemas Ltd that "the company as a whole', does not . . . mean the company as a commercial entity distinct from the corporators. It means the corporators as a general body."6

Stakeholder theorists, on the other hand, advocate an expanded corporate constituency by defining the interests of the company not only with reference to the interests of its shareholders, but also with reference to the interests of creditors, employees, customers, society and so forth. Those embracing the shareholder model are not necessarily opposed to the interests of other stakeholders being recognised, but view the shareholder model as the most likely to ensure "greater good" to all. This "utilitarian philosophy" is summarised well by Roe:

The utilitarian justifi cation is that this preference is the price paid for strong capital markets, and allocative effi ciency ... In the long run, the argument goes, employees

J Dine, The Governance of Corporate Groups (CUP 2000) 3 identifies the contractual, communitarian and concessionary theories as theories that have been influential in shaping models of companies. For further discussion on the development and application of these theories see also S Bottomley, "Taking Corporations Seriously: Some Considerations for Corporate Regulation" (1990) 19 Federal Law Review 203, 206-213; A Keay "Tackling the Issue of the Corporate Objective: An Analysis of the United Kingdom's "Enlightened Shareholder Value Approach" (2007) 29 Sydney Law Review 577, 582-88; DA Wishart, "Models and Theories of Directors' Duties to Creditors' (1991) 14 New Zealand Universities Law Review 323.

4 See, eg Keay's "entity maximisation and sustainability model", as discussed in A Keay, "Ascertaining the Corporate Objective: An Entity Maximisation and Sustainability Model" (2008) 71 MLR 663.

5 M Havenga, "Directors' Fiduciary Duties under our Future Company-law Regime" (1997) 9 South African Mercantile Law Journal 317. For a discussion on possible interests in a company see also RG Beuthin, "The Range of a Company's Interests" (1969) 86 South African Law Journal 155.

6 [1951] 1 Ch 286, 291 (emphasis added). For criticism about the importance that has been attached to this case, however, see D Attenborough, "How Directors Should Act When Owing Duties to the Companies' Shareholders: Why We Need to Stop Applying Greenhalgh" (2009) 20(10) International Company and Commercial Law Review 339. 
and other stakeholders are overall better off with fluid and efficient capital markets, managers need a simple metric to follow, and both wealth and, in the end, fairness are maximized by shareholders being the corporation's residual benefi ciary, with the other claimants getting what they want via contract with the corporation. ${ }^{7}$

The practical importance of identifying those whose interests should be equated with the "interests of the company" is, of course, the fact that these are the interests that should be considered by directors in fulfilling their obligations to the company and that failure to do so could give rise to a remedy for the group so affected. The ability to enforce directors' duties has thus become a key aspect of this debate, and criticism against the notion of an expanded corporate constituency often relies on the inability of other stakeholders to take action against directors where the directors should fail to act in their interest. ${ }^{8}$ Berle noted that

[y]ou cannot abandon emphasis on "the view" that business corporations exist for the sole purpose of making profi ts for their stockholders until such time as you are prepared to offer a clear and reasonably enforceable scheme of responsibilities to someone else. ${ }^{9}$

Beyond the sphere of academic debate, the notion of an expanded corporate constituency has been recognised to some extent by the courts-as illustrated, for example, by the judicial extension of directors' duties to include creditors' interests when a company is insolvent or approaching insolvency. ${ }^{10}$

MJ Roe, "The Shareholder Wealth Maximization Norm and Industrial Organization" (2001) 149 University of Pennsylvania Law Review 2063, 2065.

$8 \quad$ T Posyniak, "Realizing a 'Pious Wish' of Peoples and BCE: Enforcement of Pluralist Theory and Corporate Environment Responsibility" (2012) 23 Journal of Environmental Law and Practice 99, 99 refers to "the incongruence between a theoretical duty to consider stakeholder interests and the reality of corporate law remedies mired in a shareholder centric perspective".

9 Berle (n 1) 1367. In a similar vein, L Sealy, "Directors' 'Wider' Responsibilities - Problems Conceptual, Practical and Procedural" (1987) 13 Monash University Law Review 164, 177 observes that "[a] supposed legal duty which is not matched by a remedy is a nonsense". See also A Keay, "The Ultimate Objective of the Company and the Enforcement of the Entity Maximisation and Sustainability Model" (2010) 10 Journal of Corporate Law Studies 35, 37 who acknowledges the need for an enforcement mechanism in order for a model to be of practical use.

10 See, eg in Australia, Walker v Wimborne (1975-76) 137 CLR 1; Grove v Flavel (1986) 43 SASR 410; Kinsela v Russell Kinsela Pty Ltd (in liq) (1986) 4 NSWLR 722; Bell Group Ltd (in liq) v Westpac Banking Corporation (No 9) (2008) 70 ACSR 1; and in England, Lornho Ltd v Shell Petroleum Co Ltd [1980] 1 WLR 627; Liquidator of West Mercia Safetywear Ltd v Dodd 1988 PCC CA 212. The Canadian judiciary adopted a similar reasoning in Peoples Department Stores Inc (trustee of) $v$ Wise (2003) 224 DLR (4th) 509. However, this decision was ultimately overturned on appeal to the Canadian Supreme Court in Peoples Department Stores Inc v Wise 2004 SCC 68, with the Canadian Supreme Court confirming unequivocally that the duty of directors and officers does not change when the corporation is in financial distress (at [43]). Despite this, the decision has been described as "striking for its rejection of shareholder-primacy" (see IB Lee, "Peoples Department Stores v Wise and the "Best interests of the Corporation"" (2004-05) 41 Canadian Business Law Fournal 212, 213), because of the Supreme Court's emphasis on the fact that the "best interests of the corporation" should not automatically be equated with the "best interests 
In the legislative arena the legislature had the opportunity to revisit the concept of shareholder supremacy in at least four jurisdictions in the not too distant past: corporations legislation in Australia, England and South Africa, dated 2001, 2006 and 2008, respectively, ${ }^{11}$ and in Singapore the Ministry of Finance set up a Steering Committee in October 2007 to review the Singapore Companies Act. A Joint Committee of Parliament of Australia furthermore had the opportunity to revisit the formulation of directors' duty to act in the best interests of the company and presented its fi ndings in a report titled Corporate Responsibility: Managing Risk and Creating Value in 2006. The review of corporations legislation afforded the legislature in these jurisdictions an opportunity to reconsider arguments for and against an expanded corporate constituency, and to adopt a particular legislative stance in regard to the formulation of directors' duties and the interests that should be protected in terms thereof.

The purpose of this paper is to provide a comparative overview of relevant legislation in the jurisdictions mentioned in order to illustrate the extent to which the legislatures in these jurisdictions have been persuaded to depart from the notion of shareholder supremacy, if at all, or whether the "dominance of a shareholder-centered ideology corporate law among the business, government and legal elites in key commercial jurisdictions" has indeed made its influence felt "in the reform of corporate law as well", as predicted by Hansmann and Kraakman in 2001. ${ }^{12}$ Even though the discussion will focus primarily on legislative reform in the four jurisdictions mentioned, in many cases directors' duties are provided for in terms of a dual system: statutory principles operating alongside principles of common law (or general law) in relation to directors' duties. The impact of judicial pronouncement thus cannot be ignored and will be referred to where relevant.

Of particular importance for the purposes of this analysis are those provisions which define directors' duty to act in the best interests of the company or to

of the shareholders". This is confirmed in a subsequent decision of the Canadian Supreme Court, BCE Inc v 1976 Debentureholders [2008] 3 SCR 560, 2008 SCC 69, with the Court adding that "the 'best interests of the corporation' means the maximization of the value of the corporation" (at [42]). In South Africa the extension of directors' duties to include the interests of corporate constituents other than shareholders, received scant attention by the judiciary. In some cases the judiciary seems to have left a back door open for such an approach. See, eg $S$ $v$ Hepker 1973 1 SA 472, 484 (W), in which case the court expressed the view that "directors have a duty to manage the company strictly on a basis of fairness to all those who deal with it and who have no means of knowing its internal affairs" (own emphasis). However, the implications of an expanded view of the "interests of the company" have not been properly considered or examined by the South African judiciary.

11 The South African Companies Act 71 of 2008, although signed by the President on 9 April 2009, only came into operation on 1 May 2011.

12 H Hansmann and R Kraakman, "The End of History for Corporate Law" (2001) 89 Georgetown Law Journal 439, 439. 
promote the success of the company, ${ }^{13}$ and also those providing for enforcement of directors' duties by somebody other than the company-for example, by way of the typical members' derivative action. As a members' derivative action impliedly recognises the negative impact of wrongs against the company on its members, any extension of the categories of persons who could access the derivative action could, perhaps, be seen as legislative recognition of the fact that a breach of the duty to act in the interests of "the company" impacts equally on these corporate constituents. This could further lead to it being viewed as an indication that the legislature is extending "the interests" that comprise the interests of the company. The first part of this paper will therefore attempt a comparative analysis of these provisions in the jurisdic-tions mentioned, in order to gain an understanding of the legislative approach adopted in relation to the shareholder/stakeholder debate.

However, it is submitted that any conclusion based on an analysis of statutory provisions in isolation would be oversimplistic, and would fail to recognise and appreciate the impact that the particular legal framework and broader contextual factors could have on the duty of directors to act in the best interests of the corporation-aspects that would have been considered by the respective legislatures. These factors could also have a significant impact on the way in which these statutory provisions are interpreted by the courts, thus influencing the direction in which this particular duty develops. The second part of this paper will therefore consider the broader legal and contextual framework within which directors' duties operate.

\section{B. COMPARATIVE ANALYSIS OF STATUTORY PROVISIONS}

\section{Directors' Statutory Duty to Act in the Best Interests of the Company}

\section{(a) Australia}

In Australia, directors' duty to act in the best interests of the company is provided for in terms of section 181(1)(a) of the Australian Corporations Act 2001 (Cth). This provision places an obligation on directors and offi cers of the corporation to "exercise their powers and discharge their duties in good faith in the best interests of the corporation". The standard formulation of this type of duty is

13 It should be noted that the UK Companies Act 2006, s 172 provides a different formulation of this particular duty, namely a duty of directors to "promote the success of the company". For ease of reference, the traditional formulation (duty to act in the interests of the company) will be used in this paper, unless the discussion specifically concerns the UK equivalent of the duty. 
retained, with no statutory guidance as to what comprise the "interests of the corporation".

A Joint Committee of the Parliament of Australia had the opportunity to revisit the formulation of directors' duty to act in the best interests of the corporation in its examination of the concept of corporate responsibility as an aspect of the corporate governance of Australian companies fairly recently. The inquiry was very much concerned with the extent to which organisational decisionmakers have regard for the interests of stakeholders other than shareholders; the extent to which the current legal framework, specifically in regard to directors' duties, allow for broader interests to be considered; and, finally, the question as to whether revision of the legal framework is called for. ${ }^{14}$

The parliamentary committee made clear its preference for an approach of "enlightened self-interest" in regard to directors' duties. ${ }^{15}$ This approach recognises that "investments in corporate responsibility and corporate philanthropy can contribute to the long term viability of a company even where they do not generate immediate profit" and permits directors to "consider and act upon the legitimate interests of stakeholders to the extent that these interests are relevant to the corporation". ${ }^{16}$ The parliamentary committee identified a number of drivers that would encourage corporations to expand their range of activities beyond their traditional business interests, ${ }^{17}$ and in effect noted that a strong commercial focus necessitates companies to act in a socially responsible manner, thus making the business case for corporate socially responsible behaviour. ${ }^{18}$ The emphasis on the commercial benefits of properly managing social and environmental risks leads to the conclusion that "directors should act in a socially and environmentally responsible manner . . . because such conduct is likely to lead to the long term growth of their enterprise". 19

The parliamentary committee furthermore also found that the Australian Corporations Act 2001 (Cth) does facilitate a perspective of "enlightened self-interests" in that it "permits directors to have regard for the interests of stakeholders other than shareholders", ${ }^{20}$ and consequently did not feel it

14 Joint Committee on Corporations and Financial Services, Parliament of Australia, Corporate Responsibility: Managing Risk and Creating Value (2006) Terms of Reference, vii.

ibid xiv, [4.39].

ibid [4.32].

17 These include the importance of attracting investment (25), attracting and retaining employees (26), and the recognition of reputation as a valuable intangible company asset (28).

18 However, it should be noted that not everybody agrees that corporate social responsibility has that much of an impact on financial well-being of company. Commentators such as D Vogel, The Market for Virtue: The Potential and Limits of Corporate Social Responsibility (Brookings Institution 2005) 41, as referred to in Corporations and Markets Advisory Committee, The Social Responsibility of Corporations (December 2006) 42, is of the opinion that "[p]articular firms succeed or fail for many reasons, but exemplary or irresponsible social or environmental performance is rarely among them".

19 Joint Committee on Corporations and Financial Services (n 14) [4.39].

20 ibid [4.78]. 
necessary to recommend that an amendment to the directors' duties provisions within the Corporations Act is required. ${ }^{21}$ The existence of a network of legislation, in terms of which the social and environmental performance of corporations is already regulated, provided further argument against the need for any amendment to the statutory formulation of directors' duty to act in the best interests of the company. 22

The Australian Corporations and Markets Advisory Committee (CAMAC) furthermore issued a report titled The Social Responsibility of Corporations in 2006.23 It likewise indicated that there is no need to consider any legislative changes to the statutory statement of directors' duties and stated that 'directors have adequate flexibility under current law to act in a socially responsible manner". ${ }^{24}$ CAMAC indicated unequivocal support for retaining accountability to shareholders and explicitly rejected a pluralist approach, on the basis of its potential to undermine effective corporate governance and ultimately being counter-productive. ${ }^{25}$

CAMAC expressly indicated agreement with submissions made by the public regulator, the Australian Securities and Investments Commission (ASIC). ASIC highlighted concerns about uncertainty that would be created should legislation mandate a stakeholder or pluralist approach in relation to directors' duty to act in the best interests of the corporation, and in particular noted the impact that such uncertainty would have on the ability of ASIC to enforce the law in relation to directors' duties. 26

\section{(b) United Kingdom}

Company law in the UK underwent an extensive review, which process commenced with the establishment of the Company Law Review Steering Group in 1998 by the Department of Trade and Industry. The consultation paper, ${ }^{27}$ published on the day of the launch, emphasises enhancing competitiveness as one of the key objectives of the review ${ }^{28}$ and identifies the formulation of

21 This is in line with the view held by a number of commentators. See, eg J McConvill, "Directors' Duties to Stakeholders: A Reform Proposal Based on Three False Assumptions" (2005) 18 Australian Journal of Corporate Law 88, 101, who indicates that there is "simply no need to broaden the duties of directors to include obligations to take account of interests of certain classes of stakeholders other than shareholders".

22 Joint Committee on Corporations and Financial Services (n 14) [4.62].

Corporations and Markets Advisory Committee (n 18).

ibid 79, 111.

ibid 79, 111-12.

As referred to in Corporations and Markets Advisory Committee (n 18) 112.

Modern Company Law for a Competitive Economy (March 1998).

28 References to competitiveness abound in the document. The opening paragraph of the foreword indicates that company law is "fundamental to our national competitiveness"; the foreword continues to emphasise that care should be taken to "ensure that we have a framework of company which is . . competitive"; the introduction makes it clear that the government "is 
directors' duty to act in the interests of the company as one of the key issues of the review. 29 The question is posed whether "directors' duty to act in the interests of their company should be interpreted as meaning simply that they should act in the interests of the shareholders, or employees, creditors, customers, the environment, and the wider community". 30

The Steering Group expressed itself to be in favour of an "overall pluralist objective" in that companies should be managed in a way which "maximises overall competitiveness and wealth and welfare for all". 31 However, it ultimately rejected a pluralist or stakeholder approach insofar as the formulation of directors' duties is concerned on the basis of a number of policy reasons and technical concerns. Policy arguments against a pluralist formulation of the duty include the fact that it would confer too broad a policy discretion on direc-tors; that it would not necessarily be successful in achieving its objective; that it would be unnecessary if the duty is formulated in an inclusive manner; and that external benefi ts are better secured by specifi c legislation, such as employment and environmental legislation. ${ }^{32}$ Technical concerns relate to matters such as the relationship between a pluralist duty and other typical directors' duties, for example the proper purpose duty; the inconsistency that would exist between leaving shareholders' powers intact, while requiring directors to focus on broader interests in fulfi lling their obligations; the confl ict that could exist between the interests of the various stakeholders; ${ }^{33}$ and ultimately the practical problem of how a duty to a broader constituency should be enforced. 34

After a period of extensive consultation, the Companies Act 2006 was passed in the UK and fully implemented on 1 October 2009. The relevant directors' duty is provided for in terms of section 172(1) of the UK Companies Act 2006. This provision contains a list of factors and interests that should be considered by directors in "promoting the success of the company for the benefits of its members", 35 such as the likely consequences of any decision in the long term; the interests of the company's employees; the importance of the company's business relationships; the impact of the company's operations on the community and the environment; the importance of maintaining a reputation for high standards of business conduct; and the need to act fairly between members

determined that the nation should have an up-to-date framework which promotes the competitiveness of UK companies" etc (own emphasis)

29 Modern Company Law for a Competitive Economy (March 1998) [3.7].

30 ibid.

31 Modern Company Law for a Competitive Economy: Developing the Framework (DTI, March 2000) URN 00/656, [2.21].

32 ibid [3.24]. This is in line with the view posited by Hansmann and Kraakman (n 12).

33 ibid [3.27]-[3.31].

34 Modern Company Law for a Competitive Economy: Completing the Structure (DTI 2000) URN 00/1335, ch 3.5 .

35 UK Companies Act 2006, s 172(1). This formulation deviates from the traditional "in the best interests of the company" formulation. 
of the company. ${ }^{36}$ Directors are not confined to considering only those factors listed in section 172(1), as indicated by the phrase "amongst others". This leads to the assumption that it is still in the hands of the directors to decide which factors should be considered, and what relative weight should be given to these, in managing the business of the company. One aspect that is not left to the discretion of the directors, however, is the fact that the company should be managed "for the benefit of its members as a whole". 37 The formulation of this particular duty could, on the face of it, create the impression that the UK legislature had moved towards recognising an enhanced corporate constituency through its "enlightened shareholder value" approach in respect of directors' duties, also referred to as an "inclusive" formulation of the duty. ${ }^{38}$ However, the emphasis that the legislature placed on members' interests as still being the primary concern, together with the explicit rejection of pluralist approach in regard to the formulation of the duty in discussion documents, ${ }^{39}$ leaves no doubt that, ultimately, the interests of the members of the company are still paramount-a view supported by numerous commentators. 40

\section{(c) South Africa}

The extensive overhaul of South African company law took off with the publication of a policy paper entitled South African Company Laufor the 21st Century-Guidelines for Corporate Law Reform by the Department of Trade and Industry. ${ }^{41}$ The document contains a strong emphasis on social welfare objectives to be recognised in corporations legislation and thus seems to favour the concessionary theory of the corporation, which emphasises aligning the aims of the company with those of society. 42 This is evidenced by references, for example, to the fact that companies are "central to a country's economy and its

36 As provided for in terms of the UK Companies Act 2006, s 172(1). The interests of company creditors are not mentioned specifically in terms of s 172(1). However, s 172(3) provides that the duty in terms of $\mathrm{s} 172$ "has effect subject to any enactment or rule of law requiring directors, in certain circumstances, to consider or act in the interests of creditors of the company". It is submitted that this construction indicates that the common law position in respect of duties to creditors is maintained - a view shared by commentators such as Davies (n 2) 521 and Keay (n 3) 593.

37 UK Companies Act 2006, s 172(1).

38 URN 00/656 (n 31) viii.

39 URN 00/1335 (n 35) ch 3.5.

40 See, eg S Worthington, "Reforming Directors' Duties" (2001) 64 MLR 439, 440, who describes the formulation of the duty as "distinctly pluralist in objective" but "avowedly traditionalist in substance"; Rt Hon Lady Justice DBE Arden, "Companies Act 2006 (UK): A New Approach to Directors' Duties" (2007) 81 Australian Law Journal 162, 165, according to whom the enlightened shareholder approach "acknowledges that at the end of the day it is the interests of shareholders which count"; Keay (n 3) 579, who is of the opinion that "the enlightened shareholder value approach is . . . little different from the shareholder value approach"; Davies (n 2) 508, who describes the statutory formulation of the duty as "a modernised version of shareholder primacy".

41 Published in the South African Government Gazette 26493 of 23 June 2004.

42 Dine (n 3) 17. 
prosperity-for wealth creation and social renewal, ${ }^{43}$ that, in the running of a company, consideration has to be given "not only to economic factors but also to social and environmental ones"; 44 that a company is "a social as well as an economic institution"; 45 and accordingly that the company's "pursuit of economic objectives should be constrained by social . . imperatives". 46 The policy paper goes so far as to espouse a pluralist approach in terms of which "the interests of shareholders should be balanced with those of other stake-holders", recognising that "unlike the traditional company law position . . . stakeholder interests, in addition to those of shareholders, have independent value in certain instances". 47

Even though the policy paper, in parts, recognises the effi cacy of protecting interests other than those of shareholders in terms of legislation specifically focused on those interests, ${ }^{48}$ the emphasis on the social objectives of the new dispensation is particularly visible in the purposes of the South African Companies Act 71 of 2008, as set out in section 7-examples include the purpose to "promote compliance with the Bill of Rights as provided for in the Constitution, in the application of company law", 49 as well as the purpose to "reaffirm the concept of the company as a means of achieving economic and social benefits" 50 The relevance of section 7 is amply demonstrated in terms of section 5(1) of the South African Companies Act, which provides that the Act must be interpreted "in a manner that gives effect to the purposes set out in section 7", as well as section 158(b), which provides that, if a provision in the Act, read in its context, can be reasonably construed to have more than one meaning, the meaning that best promotes the spirit and purpose of the Act is to be preferred by the Courts.

The way in which directors' statutory duties are formulated may lead to a conclusion that the promotion of social objectives through company legislation is not developed further in the statement of directors' duties, as the South African legislature seemingly opted for an apparent traditional formulation of directors' duties. The relevant provision, section $76(3)(b)$, determines that directors are 4 (own emphasis).

ibid 26 (own emphasis).

ibid 27 (own emphasis).

ibid (own emphasis).

ibid 26-27.

48 Reasons for this approach include the creation of a level playing field for South African incorporated companies and overseas companies; the prevention of implementation of social change in a fragmented manner and avoiding multiplicity of "unnecessary and avoidable litigation". See South African Company Law for the 21st Century (n 43) 27.

49 South African Companies Act 71 of 2008, s 7(a).

50 South African Companies Act 71 of 2008s, 7(d). 
required to act "in the best interests of the company". 51 Nolegislative indication is given as to whose interests the interests of the company should comprise, or which factors that should be taken into consideration to determine the "best interests of the company". A narrow reading of this provision thus appears to indicate that the emphasis placed on the pluralist approach in the policy document was overlooked in the formulation of directors' duties.

However, commentators are of the opinion that the new South African Companies Act 71 of 2008 , read in its totality, provides for consideration of wider interests. Some suggest that the South African Companies Act "directly provides a clear framework for the empowerment of stakeholders and includes a directive that companies operate to enhance not only shareholder profi ts but also social welfare" 52 and that it "provides for much broader stakeholder protec-tions that would be found in similar statutes in . . . the United Kingdom". 53 Others suggest that the South African legislature adopted an approach "which lies somewhere between pluralism and the enlightened shareholder value approach". 54 Particular signifi cance is attached to section $7(\mathrm{~d})$, and it has been said that "against the background of the Policy Document section $7(\mathrm{~d})$ should also be interpreted to mean that directors must pay attention to the interests of stakeholders, but that it does not provide stakeholders with direct rights". 55

These statements seemingly ring true in light of the statutory emphasis placed on the realisation of social objectives in the South African Companies Act 71 of 2008. As the legislature opted to leave the meaning of the phrase "the interests of the company" in the hands of the courts, a purpo-sive approach to interpreting directors' duties, especially in the context of the purposes of the Act in terms of section 7 of the South African Companies Act 71 of 2008, could lead the South African judiciary to attach a wider meaning to the "interests of the company" in order to, for example, allow access to the remedy under section 218(2) to enable a corporate stakeholder to take action against a director in breach of his/her statutory duties. Thus, the extent to which the interests of other stakeholders will be incorporated under the umbrella of the "interests of the company" remains open to conjecture and still very much a matter of judicial interpretation.

1 South African Companies Act 71 of 2008, s 76(3)(b).

52 JF Olson, "South Africa Moves to a Global Model of Corporate Governance but with Important National Variations" in TH Mongalo (ed), Modern Company Law for a Competitive South African Economy (Juta \& Co 2010) 220.

53 ibid 225.

54 R Cassim and F Cassim, "The Reform of Corporate Law in South Africa" (2005) 16 International Company and Commercial Law Review 411, 412.

55 I Esser, "Corporate Social Responsibility: A Company Law Perspective" (2011) 23 South African Mercantile Law Journal 317, 324. 
Singapore companies are regulated in terms of the Singapore Companies Act. 56 This legislation was enacted in 1967 and is largely based on the Malay-sian Companies Act 1965, which in turn derives from the Companies Act 1961 (Victoria) in Australia. Several changes were made to the Act resulting from the fi ndings of the review conducted by the Company and Legislation and Regulatory Framework Committee, which issued its final report in October 2002. 57

The Singapore Companies Act provides for duties of directors in terms of section 157. In terms of subsection (1), a director is required to "act honestly and use reasonable diligence in the discharge of the duties of his offi ce". Subsection (2) further requires of offi cers and agents not to "make improper use of any information acquired by virtue of his position as an offi cer or agent of the company to gain ... an advantage for himself or for any other person or to cause detriment to the company". A director who is in breach of any of the provisions of section 157 will be liable to the company for any profit made by the director or for any damage suffered by the company, 58 and could also incur criminal liability. 59 Even though the Singapore Companies Act does not expressly indicate to whom these duties are owed, the fact that directors in breach of the duties under section 157 are liable to the company seems to confirm that these duties are owed to the company and not to its stakeholders.

However, section 159 of the Singapore Companies Act expressly provides that directors of a company, in exercising their powers, are entitled to have regard to "the interests of the company's employees generally, as well as the interests of its members". 60 Although this may seem to signal a departure from a purely shareholder-centric view of the corporation, the fact that the provision only permits directors to have regard to the interests of employees, in conjunction with the lack of any meaningful remedy by which employees would be able to commence action on the basis of directors' failure to have regard to their interests, compel one to conclude that the Singapore legislature has not opted for a stakeholder or pluralist approach in relation to directors' duties. Statements to the effect that section 159 is "a recognition that benefiting the employees generally advances the interests of the company as a commercial entity" 61 support the conclusion that section 159 does not signal the adoption of a stakeholder approach by the Singaporean legislature.

That said, the inclusion of shareholders' interests under the same provision in terms of which directors may have regard to employees' interests does seem to provide an indication that directors, in complying with

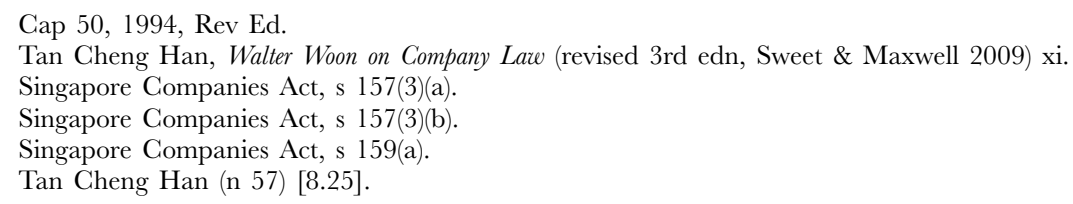


their obligations to the company, are not required to focus exclusively on the interests of the company's shareholders. Thus, although section 159 does not clearly point towards the Singaporean legislature favouring a stakeholder approach, it does seem to move away from the notion that the interests of the corporation are automatically to be confi ned to the interests of its shareholders.

The Singaporean Ministry of Finance furthermore set up a Steering Committee in October 2007, tasked with carrying out a fundamental review of the Companies Act. A key focus of the review is to "provide flexibility and clarity to directors and management of enterprises in the operation of corporate entities, but without compromising the interests of stakeholders and the public". 62

The main issue considered by the Steering Committee in regard to directors' fiduciary duties is whether the duty to act in good faith in the best interests of the company should be codified. ${ }^{63}$ The final recommendation is that "[i]t would not be desirable to exhaustively codify directors' duties". ${ }^{4}$ Although the Steering Committee referred to the UK Company Law Review in the context of its discussion on the statutory statement of directors' duties in Singapore, little attention was given to the questions as to whose interests should compose the interests of the company and whether it is necessary to amend the legislation on directors' duties in any way to reflect a particular approach. In its recent response to the report of the Steering Committee, the Singaporean Ministry of Finance indicated that it accepts the recommendation that it would not be desirable to exhaustively codify directors' duties, but that it will continue to monitor developments in the UK and other leading jurisdictions. ${ }^{65}$ Once again, no mention is made of the shareholder/stakeholder issue.

\section{Statutory Derivative Action as Enforcement Mechanism}

As indicated previously, much of the debate in this context focused on the way in which directors' duties could be enforced, rather than only on the way in which these duties are formulated. Consequently, an expansion of the category of persons who may be able to take action against directors in breach of their duties to the corporation, be it personally or through the juristic person of the company, may serve to indicate a legislative step in moving

62 Ministry of Finance, "Consultation Paper: Report of the Steering Committee for Review of the Companies Act" (June 2011) 42 <http://app.mof.gov.sg/data/cmsresource/public\%20consultation/2011/Review\%20of\%20Companies \%20Act \% 20and \%20Foreign \% 20Entities\%20Act/ Annex\%20A\%20SC\%20Report\%20Complete\%202.pdf> accessed 7 August 2012.

63 Ministry of Finance, "Consultation Paper: Report of the Steering Committee for Review of the Companies Act" (June 2011) 1-24-1-28.

64 ibid 1-28 (Recommendation 1.22).

65 Ministry of Finance, "Ministry of Finance's Responses to the Report of the Steering Committee for Review of the Companies Act" (3 October 2012) 16 <http://app.mof.gov.sg/data/cmsresource/SG_RGA_Final/AnnexA_SG_RCA.pdf> accessed 19 November 2012. 
towards a more stakeholder oriented model of the corporation.

In Australia, the ability to bring proceedings on behalf of a company is limited to a member, former member or person entitled to be registered as a member of the company or of a related body corporate, as well as an officer or former officer of the company. 66

Although the scope of the derivative action has been widened considerably by statute in the UK, the availability of the derivative action in terms of section 260 is, as in Australia, still clearly linked to a person's status as a shareholder of the particular company. 67 The increased focus on the interests of other corporate constituents evidenced by section 172 of the UK Companies Act 2006 is clearly not developed any further in terms of the derivative action provision.

In South Africa the categories of persons who may access a derivative action has been considerably widened in terms of section 165 and now includes employees ${ }^{68}$ and directors, ${ }^{69}$ whereas the predecessor to section $165^{70}$ limited access to a derivative action to members of the company. This may lead to the conclusion that a statutory broadening of constituents who may access the derivative action to protect the "interests of the company" indicates a concomitant broadening of the interests that should be included under the umbrella of the "interests of the company". 71 Noteworthy in this respect is the inclusion of employees under this provision, and it is conceivable that employees may turn to the derivative action in order to protect their interests in the company. On the other hand, the inclusion of employees under the derivative action may just be a result of the practical realities of the South African political landscape, with trade

66 Australian Corporations Act 2001 (Cth), s 236.

67 For analyses of the new UK statutory derivative action see A Keay and J Loughrey "Something Old, Something New, Something Borrowed: An Analysis of the New Derivative Action under the Companies Act 2006" (2008) 124 Law Quarterly Review 469; M Almadani, "Derivative Actions: Does the Companies Act 2006 Offer a Way Forward?" (2009) 30(5) Company Lawyer 131; D Arsalidou, "Litigation Culture and the New Statutory Derivative Claim" (2009) 30(7) Company Lawyer 205.

68 Who will typically act through trade unions or employee representatives, as recognised by the South African Companies Act 71 of 2008.

69 C Stein, "Big Businesses Beware - Class and Derivative Actions Are Coming", Without Prejudice (April 2009) 4 indicates that the new s 165 "change(d) the law, the scope and the procedure in relation to derivative actions, all in favour of shareholders and other stakeholders". See also P Hobson, "Directors Can Expect Heightened Shareholder Activism under the New Companies Act", Taxtalk (July/August 2010) 24, who suggests that "[d]irectors will be personally liable for breaches of their fiduciary duties and may be sued for loss and damage caused to creditors, employees, customers, competitors, shareholders or other stakeholders of a company".

70 South African Companies Act 61 of 1973, s 266.

71 This argument does not apply to directors, who may be seen to have been included in the provision for purely pragmatic reasons, namely to increase access to a derivative action and to permit "minority directors', for example, to act to protect the interests of the company. An argument that the inclusion of directors under this provision indicates that their interests in the company should be protected by directors is clearly doctrinally flawed. 
unions being very influential players. ${ }^{72}$ Employees' interests are furthermore very well protected in terms of labour legislation 73 and only time will tell if they will feel the need to make use of the derivative action to protect their interests in the company.

The Singaporean derivative action is only available in respect of companies not listed on the securities exchange in Singapore, ${ }^{74}$ and can generally be instituted by a member of the company 75 or by any other person whom the court regards as "a proper person to make an application" under section $216 \mathrm{~A} .{ }^{76}$ The potential extension of the derivative action to persons other than members may indicate development towards broadening the corporate constituency. However, express provision is made that an action may only be brought where it appears to be "prima facie in the interests of the company that the action be brought, prosecuted, defended or discontinued" ${ }^{77}$ An application to court for standing to access the derivative action would thus have to be supported by a clear indication that the purpose of the action is to protect the interests of the company. In the absence of any indications to the contrary, it is unlikely that stakeholders would be able to demonstrate that failure to act in their best interests is to be equated to failure to act in the best interests of the company.

\section{Summary and Analysis}

The formulation of directors' duty to act in the interests of the corporation or to promote the success of the company indicates nuance differences, the impact of which should not be underestimated. A distinction could be drawn between a statement of the duty that is "permissive", in other words which expressly allows directors to consider broader interests; a statement that is "directive", or expressly requires directors to consider broader interests; 78 and an open-ended statement, which does not give any indication as to how the phrase

72 A point illustrated by other provisions of the South African Companies Act as well. See, eg s 20(4), in terms of which trade unions representing company employees are included in the category of persons who "may take proceedings to restrain the company from doing anything inconsistent with the Act", and s 162(2), which provides employees, along with the company, a shareholder, director, company secretary or prescribed officer, with the ability to apply to a court for an order to declare a director "delinquent or under probation".

73 Specifically in terms of the South African Labour Relations Act 66 of 1995. See further I Esser, "Recognition of Various Stakeholder Interests in Company Management" (LLD thesis, University of South Africa 2008) 146-56 for a discussion and analysis of various mechanisms in terms of which the interests of employees are protected.

74 Singapore Companies Act, s $216 \mathrm{~A}(1)$. The reason for omitting listed companies from the provision is because of concerns that unscrupulous people wold make vexatious applications to harass listed companies and in that way manipulate the share price: see Tan Cheng Han ( $\mathrm{n}$ 57), 380, n 178.

75 Singapore Companies Act, s 216A(1)(a).

76 Singapore Companies Act, s 216A(1)(c).

77 Singapore Companies Act, s 216A(3)(c) (own emphasis).

78 Joint Committee on Corporations and Financial Services (n 14) 53-59. 
"the interests of the company" should be interpreted.

The UK is the only jurisdiction in which the legislature adopted a direc-tive approach, mandating directors to have regard to a range of matters in promoting "the success of the company for the benefit of its members as a whole". ${ }^{79}$ The mandatory nature of section 172(1) of the UK Companies Act 2006 furthermore indicates that the inclusion of interests, other than those of shareholders, does not merely serve to "protect" directors against liability where they do not act exclusively in the interests of shareholders (in other words, permitting them to consider other interests), but in fact requires them to take these interests into consideration. However, the UK Companies Act 2006 does not provide the interest groups listed in section 172(1) with a remedy in case directors fail to take their interests into account as required by this provision, as the enforcement of directors' duties still rests with the company, or with members of the company who have the exclusive right to utilise the derivative action. 80 As a result, some commentators observe that the charge of "tokenism" could be levelled against section 172.81

The Australian Parliamentary Joint Committee, in its interpretation of the Australian Corporations Act 2001 (Cth), adopted a different approach to the one taken by the legislature in the UK by rejecting a directive approach, on the basis of concerns that directive legislation would breed "a culture of compliance". 82 It also warned against a permissive approach in a statutory formulation, as this may eventually amount to "shifting the goalposts rather than dealing with the problem". 83 The committee found that the current open-ended formulation of directors' duties "permits directors to have regard for the interests of stakeholders other than shareholders" 84 without placing directors under an obligation to do so, 85 and recommended retention of the existing formulation. This decision is based on the fact that court judgments do not demonstrate the judiciary taking a narrow view of directors' duties, and the committee added that "[i]f a history had

9 UK Companies Act 2006, s 172.

80 UK Companies Act 2006, s 250.

81 JL Yap, "Considering the Enlightened Shareholder Value Principle" (2010) 31(2) Company Lawyer 35. See also P Omar, "In the Wake of the Companies Act 2006: An Assessment of the Potential Impact of Reforms to Company Law" (2009) 20(2) International Company and Commercial Law Review 44, 48, who describes the lack of an enforcement mechanism as the "downside" of the provision.

82 Joint Committee on Corporations and Financial Services (n 14) [4.48]. The Joint Committee of the Australian Parliament referred to a submission made by the Chartered Secretaries of Australia (CSA) in this regard, according to which mandatory consideration of stakeholder interests "would likely become a compliance-driven, box-ticking exercise, rather than an innovative, value-creating opportunity to improve performance".

83 Joint Committee on Corporations and Financial Services (n 14) [4.55].

84 ibid [4.78].

85 Corporations Market and Advisory Committee (n 18) [3.12] indicates a similar viewpoint in its report. 
emerged of court judgments taking a narrow view of directors' duties, interpreting the law in such a way as to suggest that corporate responsibility did involve risk to directors, then the committee would consider a permissive provision". ${ }^{86}$ The way in which the Australian statutory derivative action is formulated furthermore does not indicate legislative departure from the traditional shareholder-oriented approach to corporate governance, as the action is linked to a person's status as member of the company.

The South African legislature also opted for retaining a traditional formulation of directors' statutory duty to act in the best interests of the company, and the South African Companies Act 71 of 2008, similar to the Australian Corporations Act 2001 (Cth), does not provide a clear indication of whose interests will fall under the umbrella of the "interests of the company". However, the emphasis on social objectives in the Policy Document, as well as provisions of the South African Companies Act, ${ }^{87}$ appears to point directors towards paying attention to the interests of a broader range of stakeholders. 88 Furthermore, the statutory extension of those who can access the derivative action, specifically with reference to the inclusion of employees, could also be regarded as indicative of a legislative shift with regard to the concept "the interests of the company". This "shift" could perhaps, in reality, be attributed to the large amount of political power in possession of South African trade unions, as much as it could be indicative of a policy decision to expand the corporate constituency in this way. Be that as it may, it would behove the prudent South African company director to pay careful attention to the impact that corporate decisionmaking could have on the interests of company employees in particular.

The Singaporean legislature similarly seems to have retained the traditional approach in relation to the duty of directors to act in the interests of the company, as indicated by the formulation of directors' duty in this regard, as well as parties who can access the Singaporean statutory derivative action. The formulation of the duty does, however, signal that the interests of the company are not confi ned to the interests of its shareholders and that directors are free to consider the interests of employees.

The apparent retention of the traditional formulation in regard to directors' duties to act in the interests of the company could be in recognition of the fact that the inclusion of a range of other interests under interests that should be protected by directors in discharging their duties to the company is fraught with numerous problems, the most obvious one probably being the difficulty in enforcing such duties. In addition, such an approach would place a burden on directors, who would be required to judge how much weight should be

ibid.

In particular ss 5(1), 7(d) and 158(b), as discussed above.

Esser (n 55) 324. 
attached to particular interests at any given point in time, so as to steer clear from the increased risk of personal liability.

However, as indicated previously, any deeper analysis of directors' statu-tory duty to act in the interests of the company or to promote the success of the company is dependent on an appreciation of the impact of contextual factors in this sphere. These contextual aspects and their potential impact will be discussed below.

\section{IMPACT OF BROADER LEGAL AND CONTEXTUAL F RAMEWORK}

\section{Relationship between Statutory Duties and Relevant Common Law Principles}

The status of general law principles pertaining to directors' duties, compared to statutory principles, could be an important factor when considering the way in which directors' statutory duties are expressed in terms of legislation. This is particularly apparent in the formulation of directors' duties in the UK. The UK Companies Act is the only one which expressly provides that statutory principles in relation to directors' statutory duties, even though based on common law rules and equitable principles, "have effect in place of those rules and principles as regards the duties owed to a company by a director". 89 The only part of directors' common law duties that is expressly retained is the duty in terms of which directors are required, in certain circumstances, "to consider or act in the interests of creditors of the company". 90 It is interesting to note, then, the omission of "creditors' interests" from the list of factors that directors are required to consider in "promoting the success of the company for the benefit of its members". 91

The respective legislatures in both Australia and Singapore adopted the opposite approach, and in both these jurisdictions the operation of general law principles in relation to directors' duties are expressly retained alongside the statutory statement of directors' duties. ${ }^{92}$ Leading commentary on South

\footnotetext{
UK Companies Act 2006, s 170(3).

UK Companies Act 2006, s 172(3).

UK Companies Act 2006, s 172(1).

2 See Australian Corporations Act 2001 (Cth), s 185(a), which provides that statutory provisions relating to directors' duties "have effect in addition to, and not in derogation of, any rule of law relating to the duty or liability of a person because of their office or employment in relation to a corporation"; as well as the Singapore Companies Act, s 157(4), which provides that the statutory provision in relation to directors' duties "is in addition to and not in derogation of any other written law or rule of law relating to the duty or liability of directors or officers of a company".
} 
African companies legislation also indicates that the common law in respect of directors' duties will still apply insofar as it does not conflict with legislation. ${ }^{93}$

One could therefore argue that a codification of principles in regard to directors' duties, as in the UK, requires a clearer statutory statement as to what is expected of directors insofar as their duty to act in the interests of the company (or "to promote the success of the company") is concerned, as less room is left for judicial development of the content of the duty. By the same token, parallel application of general law principles in regard to directors' duties could indicate more flexibility insofar as the interpretation of the content if the duty is concerned and would fit better with an open-ended approach to this particular duty of directors.

\section{Enforcement of Directors' Duties}

Another aspect that merits consideration is the potential impact that the type of regulatory system, particularly insofar as the enforcement of directors' duties is concerned, could have on the way in which directors' duties are perceived, and perhaps even on the way in which these duties continue to develop.

Both the Australian Corporations Act 2001 (Cth) and the South African Companies Act 71 of 2008 provide for avenues to complain about director conduct, other than private suits directly through the court system. In Australia, ASIC has an important role to play with respect to the enforcement of directors' duties. ASIC is endowed with the power, amongst other things, to "take whatever action it can take, and is necessary, in order to enforce and give effect to laws of the Commonwealth that confer functions and powers on it". 94 The enforcement of directors' duties furthermore operates as part of a pecuniary penalty regime, in terms of which directors could be held liable for payment of a civil penalty to the Commonwealth, 95 in addition to liability to pay compensation to the corporation for damage suffered as a result of a breach of directors' statutory duties. ${ }^{96}$ ASIC may apply for a pecuniary penalty order, 97 whereas the corporation may apply for a compensation order. 98 The quasi-public nature of enforcement of directors' duties raises the question as to whether the public interest should play a more significant role in determining whether directors complied with their duties to the company, and commentators have asked the question: "What role does the

93 For a detailed discussion on the partial codification of directors duties in South Africa and arguments in favour of such approach and against it, as well as the application of the common law duties, see PA Delport and Q Vorster, Henochsberg on the Companies Act 71 of 2008 (4th edn, LexisNexisButterworths 2012) 287.

94 Australian Securities and Investments Commission Act 2001 (Cth), s 1(2)(g).

95 Australian Corporations Act 2001 (Cth), s 1317G.

96 Compensation to the corporation is provided for in terms of the Australian Corporations Act 2001 (Cth), s 1317H.

97 Australian Corporations Act 2001 (Cth), s 1317J(1).

98 Australian Corporations Act 2001 (Cth), s 1317J(2). 
public interest play in the enforcement of these statutory duties?"99 One could infer from ASIC's involve-ment in the enforcement of directors' duties, coupled with the operation of the civil penalty regime, that "there are substantial public interest factors at work and that the purpose of ASIC is not charged solely with protecting the compa-ny's current shareholders". 100 It would thus seem as if there is much greater potential for public interest considerations to be considered in the context of directors' duties as a result of the particular regulatory framework. However, ASIC's apparent reluctance to embrace the notion of an expanded corporate constituency indicates that the theoretical possibility of public interest consid-erations will not necessarily find embodiment in the actual enforcement of directors' duties. ${ }^{101}$

In South Africa, the Companies and Intellectual Property Commission (the Commission) 102 and the Companies Tribunal ${ }^{103}$ could potentially play an important role with regard to the enforcement of directors' duties. This is achieved by way of a statutory provision which allows for "any person" to file a complaint with the Commission "alleging that a person has acted in a manner inconsistent with this Act", 104 which could entail a breach of directors' statutory duties. The South African Companies Act allows for a wide range of possible outcomes following an investigation at the Commission's behest, including referring the complaint to the Companies Tribunal. ${ }^{105}$ The Act furthermore provides for different stakeholders to apply for remedies by making an application before a court, the Companies Tribunal, the Takeover Regulation Panel or the Commission. 106 It is true that the establishment of such bodies does not in itself indicate a theoretical shift towards a stakeholder model in the legislative stance.

99 J Harris and others, "Shareholder Primacy Revisited: Does the Public Interest Have Any Role in Statutory Duties" (2008) 26 Company and Securities Law Journal 355, 356.

100 ibid 376.

101 With reference to ASIC's submission to the Joint Committee on Corporations and Financial Services (n 14) [4.57]. ASIC indicated that a change to the law in relation to directors' duties would create problems for ASIC in effectively performing its role as enforcement regulator. ASIC expressed its view as follows: "as an enforcement regulator on the one hand and a disclosure regulator on the $(\mathrm{sic})$ hand we can see great problems in opening up very well settled law as to what the duties of directors are. If it were felt absolutely necessary by the government - and this is a government decision - to have some change to the system, we would prefer a tightly focused disclosure solution rather than opening up the whole question of directors' duties. The upset to the business of actually changing the law would be too great: 'What are we supposed to do? Who are these stakeholders? How to [sic] we rank the priority of one stakeholder against the other?' There would be all those questions. We see problems there. With our enforcement hats on, we see that if we are not careful that might build areas into which directors who had done something wrong could go and sit and say, Actually, the reason we did this was because of these new stakeholder rules'."

102 Established in terms of the South African Companies Act 71 of 2008, s 185.

103 Established in terms of the South African Companies Act 71 of 2008, s 193.

104 South African Companies Act 71 of 2008, s 168(1)(b).

105 South African Companies Act 71 of 2008, s 170(1)(b).

106 South African Companies Act 71 of 2008, s 157. 
However, in a practical sense, it could potentially increase the ability of a range of corporate stakeholders to scrutinise director conduct and to protect their interests in the company without explicitly having to extend the category of interests that should be incorporated under the "interests of the company" in the context of a formulation of directors' duties. The South African Companies Act furthermore provides for extended standing to apply for remedies. The right to make an application or bring a matter before one of the relevant bodies may, for example, be exercised by the person contemplated in the provision of the Act, but also by someone acting on behalf of such a person or even someone acting in the public interest, with the leave of the court. ${ }^{107}$ This provision functions separately from the derivative action 108 and thus creates an additional remedy. The dual protection afforded in terms of these provisions could be significant and, according to some, the possible class action provided for in terms of section 157 and the derivative action provided for in section 165 can be seen as a "lethal" combination. 109

The enforcement model in Australia and South Africa could thus potentially contribute to an expansion of interests considered by directors in complying with their duties to the company, which is not the case in jurisdictions such as the UK and Singapore, for example, where allegations of breaches of duties are left to be pursued by companies or shareholders themselves. These jurisdictions furthermore do not provide for an alternative forum to complain about director conduct, as in South Africa.

\section{Availability of Alternative Remedies}

\section{(a) Oppression Remedy}

The oppression remedy, and the way in which it is formulated, could also have an impact on the way in which directors' duties and, more specifically, the rightful beneficiary of those duties are perceived. ${ }^{110}$ The oppression remedy is traditionally associated with the enforcement of members' personal rights. ${ }^{111}$

107 South African Companies Act 71 of 2008, s 157(1). It is furthermore made clear that this provision functions separately from the derivative action (created under s 165) and that it does not create the right to commence legal proceedings contemplated under the derivative action (s 157(3)).

108 South African Companies Act 71 of 2008, s 157(3).

109 Stein (n 69) 4.

110 The Canadian oppression remedy, provided for in terms of the Canada Business Corporations Act RS 1985, c C-44, s 241 (grounds for application) and s 238 (standing), illustrates how the oppression remedy could potentially be perceived as being available to other corporate stakeholders, specifically creditors in this instance, to protect their interests in the company.

11 Although it could also be used successfully to enforce directors' duties in some instances, as conduct that consists of a wrong to the company would also impact on the position of "members as a whole". This was recognised by the courts in Australia, for example, in cases such as Re Spargos Mining NL (1990) 3 WAR 166 and Jenkins v Enterprise Gold Mines $\mathcal{N L}$ (1992) 6 ACSR 539. 
However, should access to an oppression remedy not be limited to members but be open to a broader range of stakeholders, such stakeholders could successfully use the oppression remedy to protect their interests in the company. A broader application of the oppression remedy could lead to a conclusion that the interests of stakeholders who have access to the oppression remedy are sufficiently protected and that they do not need the protection that will be afforded by an expanded notion of the concept "the interests of the company". Such a conclusion will clearly infl uence the approach adopted by the legislature or the court in a particular jurisdiction insofar as an expanded corporate constituency is concerned.

A case in point is the Canadian oppression remedy, provided for in terms of section 241 of the Canada Business Corporations Act. ${ }^{112}$ The applicants who can access the Canadian oppression remedy are not limited to members of the company, but include security holders, creditors and directors or offi c-ers. ${ }^{113}$ The Canadian oppression remedy is unique in the sense that it is the only one which expressly provides for creditors (other than debenture holders, who will have access as security holders) to access the remedy in cases where an act or omission of the corporation or the business of the corporation is conducted in a manner, or the powers of the directors of the corporation are exercised in a manner, that is oppressive or unfairly prejudicial to or unfairly disregards their interests. Even though creditor access to the oppression remedy is not without problems, ${ }^{114}$ the fact that creditors could potentially access the oppression

112 Canada Business Corporations Act RS 1985, c C-44 (CBCA).

113 CBCA, s 241(2).

114 Standing is problematic since only parties who are listed as "complainants" as per s 238 of the CBCA may access this remedy. "Complainants" are defined as holders or former holders of securities; directors or officers, or former directors or officers; or any other person who the court deems to be a proper person to make an application under this remedy. In other words, creditors would have to overcome the hurdle of standing in order to access the oppression remedy under s 241. J Ziegel, "Creditors as Corporate Stakeholders: The Quiet RevolutionAn Anglo-Canadian Perspective" (1993) 43 University of Toronto Law Journal 511, 527 notes that it is difficult to surmise why creditors are included in s 241(2) but excluded from s 238, or to surmise which abuses the drafter had in mind, and concludes that the answers to this question is "vague and quite unsatisfactory for so important a provision". For further discussion on the availability of the oppression remedy to creditors see also D Thomson, "Directors, Creditors and Insolvency: A Fiduciary Duty or a Duty Not to Oppress" (2000) 58 University of Toronto Faculty of Law Review 31, 47-51. The Canadian judiciary furthermore indicated that it will not allow debt actions routinely being turned into oppression actions (see Royal Trust Corporation of Canada v Hordo (1993) 10 BLR (2d) 96 (Ont CJ (Gen Div)) para 12, referred to by J Sarra, "Taking the Corporation Past the 'Plimsoll Line'-Director and Officer Liability when the Corporation Founders" (2001) 10 International Insolvency Review 229, 240), raising further doubt about the utility of the oppression remedy to protect the interests of corporate creditors. In a wider context (moving beyond the way in which creditor "stakeholders" could potentially access the oppression remedy), the inclusion of "any other person who the court deems as a proper person to make an application" under s 238 could, at first glance, create the impression that the door is left open for a broader range of stakeholders to access the oppression remedy, thus potentially creating room for the idea of an expanded corporate constituency. However, the grounds upon which the oppression remedy could be instituted, as described in s 241, are 
remedy to protect their interests in the corporation causes some commentators to argue that creditors' interests will be better served by way of "further elaboration of the conditions under which a creditor will be considered to be a proper person to bring an oppression application", rather than by an expansion of the concept of the "interests of the company" to include the interests of creditors. ${ }^{115}$ This also appears to be the view that underpins judicial pronouncements of the Canadian Supreme Court on directors' duties in Peoples Department Stores Inc v Wise ${ }^{116}$ and BCE Inc v 1976 Debentureholders.17

The Australian oppression remedy, provided for in terms of section 234 of the Australian Corporations Act 2001 (Cth), seems to leave a backdoor open for stakeholders other than shareholders to make use of the oppression remedy. In terms of section 234(e) the oppression remedy may be accessed by "a person whom ASIC thinks appropriate on the basis of investigations that it conducted into the company". 118 However, the type of conduct that may give rise to the oppression remedy becoming available is conduct that is "contrary to the interests of the members as a whole" 119 or conduct that is "oppressive to, unfairly prejudicial to, or unfairly discriminatory against, a member or members whether in that capacity or in any other capacity", 120 which serves to confine the availability of the Australian oppression remedy to members of the company.

formulated in a much narrower context, with oppressive conduct being limited to conduct that is "oppressive or unfairly prejudicial to or that unfairly disregards the interests of any security holder, creditor, director or officer" (own emphasis), dispelling the idea that other stakeholders could perhaps enjoy standing under this provision. The approach of the Canadian judiciary, as illustrated by pronouncements in the vein of not permitting "debt actions routinely being turned into oppression actions", creates further doubt as to whether the oppression remedy will be available to a broader range of corporate stakeholders, in spite of the broad formulation of the standing provision, in particular s $238(\mathrm{~d})$.

115 In a similar vein, Thomson (n 114) 51 calls on courts to "articulate a clear and principled basis for permitting or denying the conversion of a creditor's claim from what would otherwise be a routine debt into an application for a powerful, discretionary remedy".

1162004 SCG 68, [48]. J Sarra, "Canada's Supreme Court Rules no Fiduciary Obligation Towards Creditors on Insolvency - Peoples Department Stores v Wise" (2006) 15 International Insolvency Review 1, 6 notes that the availability of the oppression remedy to creditors "was a key part of the court's reasoning as to why fiduciary obligation should not be extended to require directors and officers to consider the interests of creditors on insolvency".

1172008 SCC 69. The statement of the Canadian Supreme Court that "the availability of such a broad oppression remedy undermines any perceived need to extend the fiduciary duty imposed on directors by s 122(1)(a) of the CBCA to include creditors" (at [51]) provides a clear indication of the impact of such an alternative remedy.

118 Section 234(a)-(d) allows access to the oppression remedy based on the traditional link to membership and provides for an application to be made under this provision by members and certain categories of past members of the company and a person to whom a share in the company has been transmitted by will or by operation of law.

119 UK Companies Act 2006, s 232(d) (own emphasis).

120 UK Companies Act 2006, s 232(e) (own emphasis). 
Application of the UK oppression remedy ${ }^{121}$ is limited in the same way. Even though the UK Secretary of State is afforded standing to apply to court for an order, ${ }^{122}$ relief is only available in cases where the company's affairs are being conducted in a manner that is unfairly prejudicial to the interests of members generally or of some part of its members. ${ }^{123}$

The South African oppression remedy, ${ }^{124}$ in addition to providing standing to members, as is usual, also affords a director of a company the opportunity to apply for relief where an act or omission of the company, the business of the company, or the powers of a director or prescribed offi cer are being exercised in a manner that is "oppressive or unfairly prejudicial to, or that unfairly disregards the interests of, the applicant". ${ }^{125}$ As this provision expressly refers to the "interests of the applicant", it is possible for directors to turn to this remedy in an attempt to protect their own interests in the company and that an application for relief under this provision would not be limited to conduct that is considered being oppressive towards members of the company. It could there-fore be possible, for example, for directors to resist removal from offi ce if it is "oppressive or unfairly prejudicial" to do so or if it "unfairly disregards" their interests. The South African oppression remedy does not contain any reference to other stakeholders, however.

The Singapore Companies Act provides for "personal remedies in cases of oppression or injustice" in terms of section 216 . This remedy can be accessed by members or debenture holders, ${ }^{126}$ or by a person to whom shares in the company have been transmitted by operation of law. ${ }^{127}$ The provision is targeted towards conduct that is oppressive to members or debenture holders, conduct in disregard of their interests, conduct that unfairly discriminates against them, or conduct which is otherwise prejudicial to the members or debenture holders. ${ }^{128}$

Unlike the case with corporate creditors in Canada, the formulation of the oppression remedy in Australia, the UK, South Africa and Singapore does not support an inference that the interests of other stakeholders of the company are adequately protected by way of this remedy. As such, the formulation does not support an argument that these stakeholders do not need the protection that could be afforded by way of an extension of the concept "the interests of the company". This aspect could infl uence the courts in these jurisdictions to adopt a wider interpretation when considering whose interests comprise "the interests of the corporation".

\footnotetext{
21 UK Companies Act 2006, s 994.

UK Companies Act 2006, s 995.

UK Companies Act 2006, s 994(1).

South African Companies Act 71 of 2008, s 163.

25 South African Companies Act 71 of 2008, s 163(1)(a)-(c).

26 Singapore Companies Act, s 216(1).

Singapore Companies Act, s 216(7).

128 Singapore Companies Act, s 216(1)(a) and (b).
} 


\section{(b) Other Remedies}

Corporations legislation could also provide for remedies, other than the derivative action or oppression remedy, which would enable stakeholders to take action against directors in breach of their statutory duties. Examples include section 218(2) of the South African Companies Act 71 of 2008 and section 1324 of the Australian Corporations Act 2001 (Cth). In terms of section 218(2), "any person who contravenes any provision of the Act is liable to any other person for any loss or damage suffered by that person as a result of that contravention". 129 Similarly, section 1324(1) of the Australian Corporations Act 2001 (Cth) provides for injunctive relief in case of a contravention of the Act, on application of ASIC or "a person whose interests have been, are or would be affected by the conduct". Subsection (10) of the same provision indicates that the court, where it has the power to grant an injunction, also has the power to order the person in contravention of the Act to pay damages "to any other person". This provision may, for example, enable a creditor to take action against directors who are in breach of their statutory duties. ${ }^{130}$

The broad formulation of provisions such as these seemingly afford a corporate stakeholder who would not be able to access the protection afforded by the derivative action or oppression remedy the right to take action against a director in breach of his/her statutory duties (a contravention of the Act), provided that this person can demonstrate that the breach of duties caused a loss or damage to him/her personally. Thus, the point as to the identity of the benefi ciary of directors' duties effectively becomes moot in the context of determining who would be able to take action against directors where a breach of directors' duties caused harm to a particular corporate stakeholder.

However, the way in which directors' duties are formulated could still preclude an action by a person who perceives him- or herself to have suffered detriment as a result of a decision or conduct of directors under this provi-sion, as the plaintiff would have to be able to demonstrate that the harm resulted from the director(s) not having acted "in the best interests of the company"-demonstrating that the directors did not act in the best interests of the particular plaintiff stakeholder would not necessarily indicate a contra-vention of the Act and would thus not automatically lead to the remedy being available. The availability of this type of remedy to corporate stakeholders to address a breach of directors' duties to the company would thus ultimately depend on the interpretation of the "interests of the

129 Own emphasis.

130 As recognised by the court in Allen v Atalay (1994) 11 ACSR 753, 757-58, in which case the court stated that is arguable that "a creditor having a right to prove in the liquidation of a company may be a person whose interests are affected by a contravention which is alleged to have led to the diminution in value of his claim against the company". See also Airpeak Pty Ltd $v$ Fetstream Aircraft Ltd (1997) 23 ACSR 715, 721. It should be noted, however, that an opposite view was taken by the Queensland Court of Appeal in McCracken v Phoenix Constructions (Qld) Pty Ltd [2012] QCA 129. 
company" by the courts. It is submitted that the general emphasis on the longterm interests of the shareholders, or "sustainability", in giving meaning to this phrase may well improve the ability of other stakeholders to take action against directors who acted to the detriment of the company in focusing on the short-term interests of shareholders (short-term profitability) by way of remedies such as these.

\section{Impact of "Soft" Regulation}

It should also be recognised that it is not only formal legislation that could have an impact on the conduct of directors. A further layer of regulatory measures has been added in the form of soft regulation, for example through corporate governance codes, standards or guidelines. ${ }^{131}$ It is true that these regulations are in most cases not directly enforceable in any way. Their importance should not be under-estimated, however, and it is recognised that guidelines such as these could "seep into the cracks and crannies of the organisation and into the expectations of its offi cers". 132 The "non-enforceability" of these principles in a traditional way could also operate as a strength in some ways, with non-traditional enforcement, for example by way of activist pressure towards compliance or a query raised by a listing authority, operating more effectively and more speedily than traditional proceedings against directors for a breach of duties. ${ }^{133}$ The normative impact of market forces and pressures of societal expectations should furthermore not be underestimated. Commentators agree that "the end-of-history thesis may overstate the importance of shareholder-focused legal duties in constraining management" 134 and it is rightly noted that corporations "operate . . . in a complex milieu of social norms, expectations and sanctions that can be powerful moderators of conduct". ${ }^{135}$ As such, any inquiry into directors' duties that treats legislative principles as the sole or primary regulator of director behaviour falls short for failing to appreciate the impact that social norms and expectations could have on director behaviour. ${ }^{136}$ It is true that these norms and

131 D Kingsford Smith, "Governing the Corporation: The Role of 'Soft' Regulation" (2012) 18 University of New South Wales Law Journal Forum 82, 82.

132 ibid 91.

133 ibid 92.

134 Lee (n 10) 221.

135 P Redmond, "Directors' Duties and Corporate Social Responsiveness" (2012) 18 University of New South Wales Law Journal Forum 45, 53. See also E Waitzer and E Jazwal, "Peoples, BCE, and the Good Corporate 'Citizen"” (2009) 47 Osgoode Hall Law Journal 439, 463, who concur that "[i]t is fair to say that courts and legislators have, overall, tended to follow and respond to heightened societal expectations over time".

136 Redmond (n 135) 53. See also R Baxt, "Future Directions for Corporate Law: Where Are We Now and Where Do We Go from Here? The Dilemmas of the Modern Company Director" (2011) 25 Australian Journal of Corporate Law 213, 223, who recognises that "[o] ur community is much more concerned today about social and related issues in the context of corporate governance". 
principles are, once again, not enforceable in any traditional way. However, it may very well be that the "rhetorical embrace of stakeholder rhetoric" could have a significant normative impact, ${ }^{137}$ with this type of rhetoric causing a shift in the way in which corporations are managed, without the shift being dependent on any particular statutory formulation. ${ }^{138}$ It is thus submitted that an increased awareness of the impact of public expectations insofar as corporate conduct is concerned would necessarily influence director behaviour. It is furthermore envisaged that the inability of a broader range of interest groups to formally enforce directors' duties will not hamper the development of the law in this area. Shareholder scrutiny of director conduct, coupled with an appreciation of the broader effect of delinquent corporate behaviour on their share investment, could very well mean that this is indeed the only group who needs to have access to remedies to enforce directors' duties.

\section{E. CONCLUSION}

The legislative reforms in the jurisdictions mentioned in this paper, particularly with reference to the way in which directors' duty to act in the interests of the corporation is formulated, steered clear from explicitly recognising an expanded corporate constituency. Further analysis, specifically in regard to the operation of enforcement mechanisms to enforce directors' duties, also reveals strong legislative support for the traditional shareholder-oriented model of corporate governance. Any explicit reference to other stakeholders, as in the UK, does not serve to expand the corporate constituency, but emphasises that corporations should be managed with a view to the long-term benefi ts for shareholders, rather than focusing on short-term benefi ts. The central idea remains that the corporation should be managed for the benefit of its shareholders. Be that as it may, the legislative emphasis on sustainable management of corporation is to be welcomed, and it is conceivable that such an approach will contribute to directors focusing their minds on stakeholder issues and would also enable those who wish to act in the interests of a broader range of stakeholders to justify those decisions. ${ }^{139}$ Such a development would not only benefit shareholders in the long-term, but would also benefit non-shareholder constituents.

137 LM Fairfax, "The Impact of Stakeholder Rhetoric on Corporate Norms" (2006) 31 Journal of Corporate Law 675, 712.

138 As recognised by a number of commentators. See, eg N Cankar, "Transition Economies and Corporate Governance Codes: Can Self-regulation of Corporate Governance Really Work?" (2005) 5 Journal of Corporate Law Studies 285, 301; MT Moore, "Whispering Sweet Nothings': The Limitations of Informal Conformance in UK Corporate Governance" (2009) 9 Journal of Corporate Law Studies 95, 138; Baxt (n 136) 230.

139 A Dignam, "Lamenting Reform? The Changing Nature of Common Law Corporate Governance Regulation” (2007) 25 Company and Securities Law Journal 283, 295. 
Some may be disappointed with the fact that legislative developments failed to make use of the opportunity to attempt to regulate corporate behaviour through a statutory expansion of the interests that should be served by directors in fulfilling their obligations to the corporation. ${ }^{140}$ It is true that companies are influential players in modern economies-as such, their conduct could impact significantly on a vast range of interests and they could also fulfil an important function in realising particular social and policy objectives, as recognised by the South African legislature. However, it is submitted that regulating the behaviour of corporations to ensure that they are good citizens and that they act in a way to achieve broader policy goals as formulated by policy-makers is not best achieved by way of legislative adoption of the stakeholder model of the corporation, through the mechanism of directors' duties-a fact which is implicitly recognised by the legislature in jurisdictions discussed in this paper and is also supported by a number of commentators. ${ }^{141}$

A submission that a formulation of traditional directors' duties should be restricted in this way does not equate to a conclusion that broader interests are unimportant and unworthy of protection. Rather the opposite-because these "other interests" are important, it is critical that they are protected effectively. It is submitted that a continued expansion of the number and categories of interests that directors should consider in complying with their duties "to the company" will not necessarily be the best means to achieve this goal. The difficulties inherent in such an approach could have a counter-productive effect and could result in such measures coming to be regarded as mere tokenism. Express protective measures outside the arena of corporate law, rather than attaching an artifi cial construction to the "interests of the corporation", would be much more effective in achieving the objective of ensuring that corporations and their directors behave in a socially responsible fashion and will enable clearer formulation of policy objectives insofar as the purpose of corporations is concerned. ${ }^{142}$ Directors, in complying with their duties to the company, would have to ensure that

140 Commentators such as Posyniak (n 8) 132, who suggests, for example, that "[i]f one is serious about using internal, self-regulatory means to promote CER, then a clear, predictable legislative statement, coupled with useable enforcement mechanisms must be adopted".

141 See, eg JA Purcell and JA Loftus, "Corporate Social Responsibility: Expanding Directors' Duties or Enhancing Corporate Disclosure" (2007) 21 Australian Journal of Corporate Law 135, 148, who, in answering the question "as to whether the corporations law is an appropriate vehicle through which desirable environmental and social outcomes should be compelled or promoted", argue that this approach to corporate social responsibility regulation "can be challenged on several grounds" and furthermore indicate that "the embodiment of a formal duty to multiple stakeholders is potentially harmful as it introduces uncertainty into the law" (at 158). According to Sealy (n 9) 187, an extension of directors' duties "so as to embrace the interests of employees and similar groups (and a fortiori so as to include more general concerns such as the environment) is to deny any effective role for the law and the courts". See also M Havenga, "Regulating Directors' Duties" (2005) 26 Obiter 609, 615.

142 In line with the approach suggested by commentators such as Hansmann and Kraakman (n 12) 442, who note that "the most efficacious legal mechanisms for protecting the interests 
the company adheres to applicable and relevant legislation. In this way it would be possible to achieve what would have been the aim of incorporating wider interests under the concept "the interests of the corporation", but for the important fact that directors would not be required to: determine whose interests are dominant at a particular time; determine how much weight should be given to various interests; be concerned about liability to numerous stakeholders; or be burdened with having to implement undefi ned policy objectives in managing the business of the company. ${ }^{143}$ At the same time, these broader interests will be protected more effectively.

Initially, the legislative response to the shareholder/stakeholder debate in corporate governance may indeed seem to offer final support for Hansmann and Kraakman's conclusion in 2001 that "[t]he triumph of the shareholder-oriented model of the corporation over its principal competitors is now assured". 144 It is submitted, however, that the shareholder-oriented model itself has undergone significant changes, and that developments in this respect will continue, especially as a result of the increased significance of extra-legal principles and norms on corporate behaviour. An historical analysis of the development of the corporation as a form of business enterprise shows that corporations were not created by statute, but were given statutory recognition after having evolved to answer the needs of the business community of the day ${ }^{145}$ _the evolution supported by the courts' sympathetic approach to informal structures. ${ }^{146}$ This analysis could lead to the conclusion that "changes in the common law can have predictable consequences for legislative behavior". 147 Acceptance of the thesis

of nonshareholder constituencies - or at least all constituencies other than creditors - lie outside of corporate law". Sealy (n 9) 164 is of a similar mind, indicating that " $[\mathrm{t}]$ he interests of consumers, the environment, welfare and the cause of equal opportunity, good race relations and so on can only be furthered by positive legislation extraneous to company law". Advisory committees, such as the Corporations and Markets Advisory Committee in Australia, also express doubts about the "utility in looking to the Corporations Act or directors' duties to redress concerns that may arise from time to time about the environmental or social consequences of what may be perceived as irresponsible business activities" and indicate a preference for "legislative intervention . . . to address particular behaviours or activities through legislation targeted at the mischief in question" (Corporations and Markets Advisory Committee (n 18) 113).

143 The impact that such wide, undefined duties could have on directors is recognised by Purcell and Loftus (n 141) 148; see also Sealy (n 9) 186.

144 Hansmann and Kraakman (n 12) 468.

145 GM Anderson and RD Tollison, "The Myth of the Corporation as a Creation of the State" (1983) 3 International Review of Law and Economics 107, 107 suggest that "the corporate form developed and spread as an efficient market innovation which preceded legislative enactments by a long margin". See also D Millon, "Theories of the Corporation" [1990] Duke Law Journal 201, 213, who agrees that "corporations are the product of a combination of entrepreneurial initiative and the natural, impersonal forces of market competition. The older idea that states were responsible for the creation of corporate power no longer seemed appropriate."

146 HN Butler, "General Incorporation in Nineteenth Century England: Interaction of Common Law and Legislative Processes" (1986) 6 International Review of Law and Economics 169.

147 ibid 183. 
that the pattern of corporate law reform that has been established over the years invariably involves the legislature playing catch-up with the way in which common law develops, driven by expectations or pressures of society, forces an opposite conclusion from the one proposed by Hansmann and Kraakman-the tug-of-war as described in the shareholder/stakeholder debate has by no means reached its final conclusion and the debate is probably set to continue for years to come, albeit not in the legislative arena in the immediate future. 